\title{
ORZECZNICTWO
}

Agnieszka Olech

aolech@mkidn.gov.pl

orcid.org/0000-0002-0849-2797

Ministerstwo Kultury i Dziedzictwa Narodowego

Departament Ochrony Zabytków

ul. Krakowskie Przedmieście 15/17

00-071 Warszawa

\section{Glosa do orzeczenia Sądu Rejonowego w Tomaszowie Lubelskim z dnia 2 lutego 2016 roku (sygn. akt II K 662/14, niepubl.)}

Commentary on the Tomaszów Lubelski District Court's sentence dated $2^{\text {nd }}$ February 2016 (Ref. No. II K 662/14)

Summary: This commentary presents an analysis of the court's holding concerning the highly popular phenomenon of metal detecting, in the context of historical/cultural artifacts. According to the applicable law, searching for historical artifacts can only take place after obtaining the consent of the voivodeship monuments' conservator; however, this duty is not respected in the majority of cases. Moreover, such searches often lead to the destruction of archaeological sites and illegal excavation of movable artefacts. The District Court in Tomaszów Mazowiecki pointed out that searching for historical/cultural artifacts using a metal detector shows all the features of a criminal offense regulated in Art. 108, the Act on the Protection of Monuments and the Guardianship of Monuments. This offense is typified as damaging or destroying a monument.

Keywords: Archaeology, artefacts, metal detecting, archaeological site, metal detector, damage of archaeological site 
Streszczenie: Glosa została poświęcona niezwykle popularnemu w ostatnich latach zjawisku poszukiwania zabytków z wykorzystaniem wykrywaczy metali. Zgodnie z obowiązującym prawem, poszukiwania takie mogą odbywać się jedynie po uzyskaniu zgody wojewódzkiego konserwatora zabytków. W większości przypadków powyższy obowiązek nie jest jednak respektowany. Ponadto w trakcie prowadzenia wspomnianych poszukiwań dochodzi do naruszania struktury stanowisk archeologicznych i nielegalnego wydobywania zabytków ruchomych. W swoim orzeczeniu Sąd Rejonowy w Tomaszowie Lubelskim wypowiedział się co do natury i skutków takiej działalności i stwierdził m.in., że poszukiwanie zabytków na stanowiskach archeologicznych wypełnia dyspozycję art. 108 ustawy o ochronie zabytków i opiece nad zabytkami, a więc prowadzi do uszkodzenia lub zniszczenia zabytku.

Słowa kluczowe: archeologia, zabytki, poszukiwania zabytków, stanowisko archeologiczne, wykrywacz metali, uszkodzenie stanowiska archeologicznego

\section{Uwagi wstępne}

Glosowane orzeczenie dotyczy niezwykle aktualnego i niebezpiecznego dla dziedzictwa kulturowego zjawiska, jakim jest poszukiwanie zabytków z wykorzystaniem sprzętu do wykrywania metali. Zgodnie $z$ definicją zawartą $w$ art. 36 ust. 1 pkt 12 ustawy o ochronie zabytków i opiece nad zabytkami ${ }^{1}$ (dalej: u.o.z.), poszukiwanie zabytków to działalność polegająca na poszukiwaniu ukrytych lub porzuconych zabytków ruchomych, w tym zabytków archeologicznych, przy użyciu wszelkiego rodzaju urządzeń elektronicznych i technicznych oraz sprzętu do nurkowania. Szacuje się, że to popularne "hobby” praktykowane jest w Polsce przez nawet 100 tysięcy osób. Amatorzy poszukiwań zabytków wywodzą się ze wszystkich grup społecznych - wśród nich znajdują się także politycy, prawnicy czy przedstawiciele organów ścigania. Zajęcie to przyjmuje najróżniejsze formy - od weekendowych, sporadycznych wypadów aż po metodyczną działalność, uprawianą przez dobrze zorganizowane grupy, które $z$ handlu nielegalnie pozyskanymi zabytkami uczyniły swoje stałe źródło dochodu. Sam fakt nielegalnego poszukiwania zabytków jest jednak jedynie częścią problemu. Częstym skutkiem takiej aktywności jest uszkadzanie i niszczenie stanowisk archeologicznych, czyli nieruchomych zabytków archeologicznych. Nad tym właśnie zagadnieniem pochylił się Sąd Rejonowy w Tomaszowie Lubelskim, rozpatrując sprawę oskarżonego Andrzeja R.

1 Ustawa z dnia 23 lipca 2003 r. o ochronie zabytków i opiece nad zabytkami, tekst jedn. Dz. U. z 2017 r., poz. 2187 ze zm. 


\section{Stan faktyczny}

Andrzej R., działając wspólnie i w porozumieniu z dwoma innymi, nieustalonymi sprawcami, prowadził 5 kwietnia 2014 r. poszukiwania zabytków z użyciem wykrywacza metali na obszarze dobrze rozpoznanego i ujętego w ewidencji wojewódzkiego konserwatora zabytków stanowiska archeologicznego w U. Na terenie tego stanowiska odkryto ślady ludzkiego osadnictwa sprzed ok. 4 tysięcy lat. Oskarżony wraz z towarzyszącymi osobami przeszukiwali obszar stanowiska i w celu ujawnienia znalezisk archeologicznych wykopywali w jego obrębie dołki saperką. Aktywność tę zauważyli pracownicy naukowi i studenci jednego z uniwersytetów, którzy prowadzili w pobliżu badania archeologiczne. Po przeprowadzeniu z nimi krótkiej rozmowy wszyscy trzej mężczyźni oddalili się z miejsca zdarzenia. Jakiś czas później Andrzej R. powrócił do pozostawionego nieopodal samochodu - w międzyczasie zmienił ubranie, nie miał już też przy sobie detektora metali, saperki oraz torby na znaleziska. Wezwana na miejsce Policja dokonała przesłuchania oskarżonego i świadków wydarzenia, sporządzono także oględziny miejsca i dokumentację fotograficzną zniszczeń. Kierownik badań archeologicznych złożyła formalne zawiadomienie o popełnieniu przez Andrzeja R. przestępstwa.

Sąd Rejonowy w Tomaszowie Lubelskim orzekł, że Andrzej R. dopuścił się przestępstwa unormowanego $w$ art. 108 ust. 1 u.o.z. Apelację od tego wyroku wniosła obrońca oskarżonego, zarzucając orzeczeniu m.in. przekroczenie granic swobodnej oceny dowodów, przyjęcie niewłaściwej kwalifikacji prawnej czynu oraz niewspółmierność orzeczonej kary do stopnia winy oskarżonego i społecznej szkodliwości czynu. Sąd Okręgowy w Zamościu wyrokiem z dnia 9 maja 2016 r., sygn. akt II Ka 263/16 (niepubl.) oddalił apelację, uznając ją za niezasadną i tym samym utrzymał w mocy wyrok sądu I instancji.

\section{Stanowisko archeologiczne jako zabytek}

Na wstępie kilka uwag warto poświęcić definicji i statusowi zabytku archeologicznego $w$ prawie polskim. Zgodnie z art. 3 pkt 4 u.o.z., jest on kwalifikowaną formą zabytku, określaną jako zabytek nieruchomy, będący powierzchniową, podziemną lub podwodną pozostałością egzystencji i działalności człowieka, złożoną z nawarstwień kulturowych i znajdujących się w nich wytworów bądź ich śladów, albo zabytek ruchomy, będący tym wytworem². W celu ułatwienia identyfikacji zabytku archeologicznego pojęcie to zostało dodatkowo doprecyzowane $w$ art. 6 ust. 1 pkt 3 u.o.z., w którym enumeratywnie wymieniono jego najbardziej charakterystyczne kategorie. Wśród przykładów zabytków archeologicznych znalazły się m.in. pozostałości terenowe pradziejowego i historycznego osadnictwa oraz cmentarzyska. 
Analizując pojęcie dziedzictwa archeologicznego, nie wolno zapomnieć również o ratyfikowanych przez Polskę aktach prawa międzynarodowego, w tym szczególnie o Europejskiej konwencji o ochronie dziedzictwa archeologicznego, sporządzonej w La Valetta dnia 16 stycznia 1992 r. (zwanej również konwencją maltańską) ${ }^{3}$. Konwencja maltańska definiuje ten zasób jako wszelkie pozostałości, obiekty i jakiekolwiek inne ślady ludzkości z minionych epok (art. 1 ust. 2):

- których zachowanie i analiza pomogą prześledzić historię ludzkości i jej stosunek do środowiska naturalnego,

- dla których wykopaliska i odkrycia oraz inne metody badań nad dziejami ludzkości i jej środowiskiem są podstawowym źródłem informacji.

Konwencja precyzuje również, że dziedzictwo archeologiczne obejmuje struktury, konstrukcje, zespoły budowlane, eksploatowane tereny, przedmioty, zabytki innego rodzaju, jak też ich otoczenie znajdujące się na ziemi lub pod wodą (art. 1 ust. 2).

W piśmiennictwie podejmowane są także inne próby zdefiniowania dziedzictwa archeologicznego. Przykładowo, zgodnie z propozycją wysuniętą przez Zbigniewa Kobylińskiego, za zasób taki powinno uznawać się wszelkie znajdujące się aktualnie na ziemi, pod ziemią lub pod wodą ruchome lub nieruchome materialne ślady egzystencji i twórczej lub destrukcyjnej działalności człowieka, trwale wyłączone $z$ funkcjonowania $w$ istniejącym systemie społeczno-kulturowym ${ }^{4}$.

Sąd Rejonowy w Tomaszowie Lubelskim przyjął, że czyn oskarżonego Andrzeja R. dotyczył zabytku archeologicznego. Należy z pełnym przekonaniem zgodzić się z tą interpretacją - stanowisko archeologiczne w U., kryjące ślady osadnictwa z czasów pradziejowych, z całą pewnością spełnia wymogi wskazane we wspomnianych wyżej definicjach - jest podziemną pozostałością działalności ludzkiej, która stanowi świadectwo minionej epoki, a jego zachowanie leży w interesie społecznym ze względu na posiadane wartości historyczne, artystyczne i naukowe.

Sąd trafnie przyjął również, że dla uznania danego obszaru za zabytek archeologiczny nie jest konieczne wpisanie go do rejestru zabytków ani oznakowanie go $w$ terenie. Jak zauważa się $w$ doktrynie, wpis do rejestru nie jest konstytutywny dla uznania obiektu za zabytek ${ }^{5}$. Należy w tym miejscu dodać, że dla zaistnienia odpowiedzialności karnej z art. 108 u.o.z. stanowisko nie musi być również objęte formami ochrony, o których mowa w art. 7 u.o.z., ani być ujęte w gminnej czy wojewódzkiej ewidencji zabytków. Wystarczy, że spełnia ustawową definicję zabytku archeologicznego. Dodatkowo sąd wskazał, że istnienie w miejscowości U. wielu

3 Europejska konwencja o ochronie dziedzictwa archeologicznego (poprawiona), sporządzona w La Valetta dnia 16 stycznia 1992 r., Dz. U. z 1996 r. Nr 120, poz. 564.

4 Z. Kobyliński, Teoretyczne podstawy konserwacji dziedzictwa archeologicznego, Fundacja „Res Publica Multiethnica”, Instytut Archeologii i Etnologii Polskiej Akademii Nauk, Warszawa 2001, s. 48.

5 Por. np. M. Kulik, Komentarz do przepisów karnych ustawy o ochronie zabytków i opiece nad zabytkami, teza 5, LEX [dostęp: 15.03.2017]. 
stanowisk archeologicznych było faktem powszechnie znanym. Co roku odbywały się tam badania archeologiczne, a kwestia występowania śladów przeszłości wielokrotnie pojawiała się w mediach $\mathrm{i}$ była przedmiotem licznych publikacji, programów telewizyjnych czy organizowanych lokalnie festynów. Tłumaczenia oskarżonego, że nie wiedział o istnieniu na tym terenie stanowisk archeologicznych, nie mogły więc zasłużyć na wiarę sądu. Argument nieświadomości Andrzeja R. co do statusu terenu, po którym się poruszał, podniosła również $w$ apelacji obrońca oskarżonego. Sąd Okręgowy w Zamościu potwierdził jednak interpretację sądu rejonowego, wskazując, że wszelkie okoliczności sprawy dowodziły, iż oskarżony dobrze zdawał sobie sprawę z zabytkowego charakteru terenu, na którym prowadził poszukiwania.

\section{Niszczenie stanowisk archeologicznych}

W dalszej kolejności sąd rejonowy dokonał oceny charakteru działania oskarżonego. Andrzej R. wykopywał w trakcie prowadzenia poszukiwań dołki saperką na terenie zabytku - stanowiska archeologicznego. Czynem tym bezpośrednio naruszał jego substancję i integralność, a w konsekwencji doprowadził do jego uszkodzenia. Uszkodzenie zabytku to działanie, które w przeciwieństwie do zniszczenia nie powoduje jego unicestwienia, a więc utraty wartości, dla których został uznany za zabytek $^{6}$. Dokonując subsumpcji, sąd prawidłowo zatem przyjął kwalifikację prawną, uznając, że zachowanie oskarżonego wypełniło dyspozycję art. 108 ust. 1 u.o.z. Jak się wskazuje, przedmiotem ochrony art. 108 u.o.z. jest właśnie nienaruszalność zabytku i zachowanie go $w$ stanie niepogorszonym? 7 . Jednocześnie należy stwierdzić, że odpowiedzialność karna z tego artykułu jest niezależna od wysokości szkody8.

Rozpatrując status stanowisk archeologicznych, trzeba pamiętać, że mają one własną specyfikę, bardzo różną od pozostałych kategorii zabytków nieruchomych. Ich istotą są nawarstwienia ziemne, tworzące układ wzajemnie przeplatających się warstw kulturowych, będących świadectwem działalności ludzkiej w przeszłości. Właśnie te podziemne lub podwodne struktury, pozostałości po osadach, cmentarzyskach, grodziskach czy kurhanach poddane są ochronie prawnej jako zabytki. Badając stanowiska, archeolodzy analizują odkryty układ warstw i znajdujących się w nich zabytków ruchomych, czyli tzw. kontekst archeologiczny, i na tej podstawie interpretują przebieg wydarzeń, charakterystykę

\footnotetext{
6 B. Gadecki, Ustawa o ochronie zabytków i opiece nad zabytkami. Art. 108-120. Przepisy karne. Komentarz, C.H. Beck, Warszawa 2014, s. 24.

7 Por. M. Kulik, A. Szczekala, Odpowiedzialność karna za przestępstwo zniszczenia lub uszkodzenia zabytku, w: T. Gardocka, J. Sobczak (red.), Prawna ochrona zabytków, Wydawnictwo Adam Marszałek, Szkoła Wyższa Psychologii Społecznej, Toruń 2010, s. 126; B. Gadecki, op. cit., s. 11.

8 W. Radecki, Ochrona zabytków w polskim, czeskim i słowackim prawie karnym, „Prokuratura i Prawo” 2012, nr 4, s. 21.
} 
dawnego osadnictwa czy datowanie znalezionych obiektów i artefaktów. Jeśli struktura ta zostanie naruszona przez osobę niemającą specjalistycznej wie$\mathrm{dzy}$, poprzez wykonanie przekopu przez kolejne warstwy ziemne lub wydobycie z nich zabytków ruchomych bez zadokumentowania ich dokładnego położenia przestrzennego, niemożliwa będzie już jej poprawna analiza i w konsekwencji wyciągnięcie trafnych wniosków naukowych. Osoby, które amatorsko poszukują zabytków, nie mają umiejętności pozwalających na zachowanie właściwej metodyki prac podczas eksploracji stanowisk archeologicznych. Wszelkie prowadzone przez nich działania naruszające strukturę stanowisk archeologicznych należy zatem postrzegać $w$ kategorii uszkadzania i niszczenia zabytków?

Na marginesie omawiania przedmiotowego orzeczenia można zauważyć, że niebezpieczeństwo płynące dla dziedzictwa kulturowego ze zjawiska niszczenia zabytków jest przedmiotem szczególnej uwagi ustawodawcy - nowelizacją z dnia 22 czerwca 2017 r. ${ }^{10}$ podwyższono wymiar kary za popełnienie przestępstwa unormowanego w art. 108 u.o.z. Od 9 września 2017 r. kto umyślnie niszczy lub uszkadza zabytek, podlega karze pozbawienia wolności od 6 miesięcy do lat 8 . W omawianym stanie faktycznym obowiązujące było jednak wcześniejsze brzmienie art. 108 u.o.z. - niszczenie lub uszkadzanie zabytków zagrożone było karą pozbawienia wolności od 3 miesięcy do lat 5 .

\section{Orzeczona kara}

Uznając Andrzeja R. winnym uszkodzenia zabytku na podstawie art. 108 u.o.z., Sąd Rejonowy w Tomaszowie Lubelskim stwierdził, że oskarżony działał umyślnie, w zamiarze ewentualnym, i w związku z tym sąd wymierzył mu karę 6 miesięcy pozbawienia wolności w zawieszeniu na 3 lata i karę grzywny w liczbie 100 stawek dziennych po 10 zł oraz orzekł wobec niego nawiązkę w kwocie 6000 zł na cel społeczny związany z opieką nad zabytkami. Wyjaśniając pisemnie motywy swojego orzeczenia, sąd wskazał, że powodami takiego rozstrzygnięcia był brak wątpliwości co do winy oskarżonego, znaczny stopień społecznej szkodliwości czynu, a także działanie sprawcy z niskich pobudek.

Zgadzając się w pełni z takim rozstrzygnięciem, należy jednak wskazać kilka aspektów, które nie zostały przez sąd dostatecznie wyjaśnione.

Po pierwsze sąd pozostawił termin "niskich pobudek” bez bliższego doprecyzowania. Pojęcie to, występujące w art. 40 § 2 Kodeksu karnego z 1969 r., było już

9 O częstym popełnianiu przestępstw na obszarze stanowisk archeologicznych pisze m.in. M. Trzciński, Przestępczość przeciwko zabytkom, „Prokuratura i Prawo” 2011, nr 6, s. 38.

10 Ustawa z dnia 22 czerwca 2017 r. o zmianie ustawy o ochronie zabytków i opiece nad zabytkami oraz niektórych innych ustaw, Dz. U. poz. 1595. 
w doktrynie i orzecznictwie wielokrotnie analizowane ${ }^{11}$. Przytoczyć w tym miejscu można chociażby wyrok Sądu Najwyższego z dnia 16 listopada 1973 r. ${ }^{12}$, zgodnie z którym „działanie z niskich pobudek występuje z reguły w sytuacji, w której sprawca dopuszcza się przestępstwa [...], dążąc do zaspokojenia swoich zachcianek czy wzbogacenia się bez względu na krzywdę, którą wyrządza dobru społecznemu lub jednostce", lub wyrok Sądu Najwyższego z 7 marca 1968 r. ${ }^{13}$, w którym sąd stwierdza, że za niskie można uznać pobudki, „które w odczuciu społecznym uchodzą za godne pogardy lub odrażające". W przedmiotowej sprawie można domyślać się, że sąd miał na myśli brak respektowania obowiązujących przepisów prawa oraz chęć osiągnięcia zysku poprzez nielegalne pozyskanie i ewentualną sprzedaż zabytków należących do Skarbu Państwa, jednak nie zostało to wprost wskazane. Na potencjalne korzyści materialne wskazał dopiero w swoim orzeczeniu sąd II instancji. Tymczasem, jak wynika z linii orzeczniczej Trybunału Konstytucyjnego, „podmiot stosujący prawo powinien z jednej strony jasno i klarownie wskazać wszelkie okoliczności, które uzasadniają posłużenie się zwrotem niedookreślonym, a z drugiej dokładnie wyjaśnić rozumienie danego zwrotu w konkretnej sprawie" ${ }^{14}$. Sąd Rejonowy w Tomaszowie Lubelskim powinien zatem bliżej objaśnić, na czym polegały w jego ocenie niskie pobudki oskarżonego. Dokładne wyjaśnienie tej i pozostałych podstaw skazania byłoby pożądane nie tylko ze względu na kompletność przedmiotowego uzasadnienia, ale również stanowiłoby pomocne wskazanie dla sędziów rozpatrujących podobne sprawy w przyszłości.

Po drugie sąd rejonowy był niekonsekwentny przy ocenie charakteru dotychczasowej działalności oskarżonego. W pierwszej części uzasadnienia czytamy, że sposób postępowania oskarżonego wskazuje na przemyślane i planowe działanie, a on sam poszukiwaniem zabytków musiał zajmować się od dawna (na co wskazywać ma m.in. działanie w grupie, przemieszczanie się w tyralierze, kosztowny, profesjonalny detektor metali, ubiór przystosowany do pracy w terenie czy owinięcie taśmą rączki od saperki). Według sądu okoliczności sprawy w sposób oczywisty wskazują, że nie był to pierwszy kontakt oskarżonego z pracą z użyciem wykrywacza metalu. Tymczasem przy wyjaśnianiu powodów niewymierzenia bezwzględnej kary pozbawienia wolności sąd wskazał, że „oskarżony nie był wcześniej karany, co pozwala przypuszczać, że to zachowanie miało charakter incydentalny i się wię-

\footnotetext{
11 Między innymi: J. Kulesza, Glosa do wyroku sq̨du apelacyjnego z 27 kwietnia 1999 roku, II AKa 12/99, „Palestra” 2000, nr 4, s. 294-300; M. Szerer, Komplikacje zagadnienia „niskich pobudek”, „Palestra” 1972, nr 3; B. Hołyst, Motywacyjne uwarunkowania czynu przestępnego, „Zeszyty Naukowe Uniwersytetu Łódzkiego, Prawo", Seria I, 1973, z. 99 oraz powołana w tych opracowaniach literatura i orzecznictwo Sądu Najwyższego.

12 Wyrok Sądu Najwyższego z dnia 16 listopada 1973 r., sygn. akt II KR 158/73, OSNKW 1974, nr 4, poz. 63.

13 Wyrok Sądu Najwyższego z dnia 7 marca 1968 r., sygn. akt VI KZP 9/67, OSNKW 1968, nr 5, poz. 51

14 M. Śliwka, Znaczenie zwrotów niedookreślonych na tle orzecznictwa polskiego Trybunału Konstytucyjnego, „Studia luridica Lublinensia” 2010, nr 13, s. 270.
} 
cej nie powtórzy, nawet mimo zawieszenia wykonania kary pozbawienia wolności". Te dwa stanowiska zdają się sobie przeczyć. Należy z pełnym przekonaniem zgodzić się z poglądem wyrażonym przez sąd w pierwszej kolejności - materiał zgromadzony w sprawie pozwala na stwierdzenie, że oskarżony już wcześniej zajmował się poszukiwaniami zabytków, a więc, o ile nie działał na podstawie i w granicach pozwolenia udzielonego przez wojewódzkiego konserwatora zabytków, wielokrotnie łamał prawo. Wniosek ten stawia zatem pod znakiem zapytania słuszność warunkowego zawieszenia kary pozbawienia wolności w tym przypadku.

\section{Prowadzenie poszukiwań zabytków bez pozwolenia wojewódzkiego konserwatora zabytków}

Na zakończenie należy jeszcze dodać, że w żadnym punkcie uzasadnienia ani sąd rejonowy, ani sąd okręgowy nie odniosły się do faktu prowadzenia przez Andrzeja R. poszukiwań bez odpowiedniego pozwolenia. Zgodnie zart. 36 ust. 1 pkt 12 u.o.z., na prowadzenie poszukiwań zabytków zawsze niezbędne jest pozwolenie właściwego miejscowo wojewódzkiego konserwatora zabytków. W przeciwnym wypadku poszukiwania prowadzone są nielegalnie. Czyn taki, w dacie prowadzenia poszukiwań przez oskarżonego, usankcjonowany był w art. 111 u.o.z. i stanowił wykroczenie. Oskarżony nie miał zgody właściciela terenu ani pozwolenia konserwatorskiego, a więc jego działanie wypełniło znamiona powyższego przepisu. W doktrynie wskazuje się, że jeżeli do zniszczenia lub uszkodzenia zabytku doszło w trakcie nielegalnych poszukiwań, mamy do czynienia z idealnym zbiegiem przestępstwa $z$ art. 108 u.o.z. z wykroczeniem z art. 111 u.o.z. ${ }^{15}$ Sąd powinien zatem orzec karę również za ten czyn, a jeżeli stosowny wniosek o ukaranie sprawcy z art. 111 u.o.z. nie został przez oskarżyciela wniesiony, to przynajmniej zauważyć jego popełnienie. W uzasadnieniu brak jednak jakiejkolwiek informacji na ten temat.

Tymczasem nielegalne poszukiwania stanowią ogromne niebezpieczeństwo dla zabytków archeologicznych. Dostrzegając to zagrożenie, ustawodawca zmienił, wspomnianą wyżej nowelizacją, kwalifikację prawną czynu prowadzenia poszukiwań zabytków bez stosownego zezwolenia wojewódzkiego konserwatora zabytków z wykroczenia na przestępstwo ${ }^{16}$. Należy wierzyć, że zmiana ta pozwoli na wzrost liczby wyroków skazujących za tego typu postępowanie.

15 B. Gadecki, op. cit., s. 112.

16 Ustawa z dnia 22 czerwca 2017 r. o zmianie ustawy o ochronie zabytków i opiece nad zabytkami oraz niektórych innych ustaw, Dz. U. poz. 1595. Weszła w życie 9 września 2017 r., lecz art. 109c, którego przepis nakazuje uznawać nielegalne poszukiwania zabytków za przestępstwo, zaczął obowiązywać 1 stycznia 2018 r. Zastąpił on w tym zakresie uchylony art. 111 u.o.z. Zgodnie z dyspozycją art. 109c, prowadzenie poszukiwań bez odpowiedniego pozwolenia albo wbrew jego warunkom zagrożone jest karą grzywny, ograniczenia wolności albo pozbawienia wolności do lat 2. 


\section{Konkluzje}

Poza wskazanymi wyżej uwagami należy stwierdzić, że Sąd Rejonowy w Tomaszowie Lubelskim, rozpatrując niniejszą sprawę, w sposób rzetelny zgromadził oraz ocenił materiał dowodowy. Uwzględnił m.in. zasady określone w Kodeksie postępowania karnego, $w$ tym ustanowioną $w$ art. 7 Kodeksu zasadę swobodnej oceny dowodów ${ }^{17}$. Sąd rozważył zarówno okoliczności działania oskarżonego, zeznania świadków, jak i zabytkowy charakter terenu, po którym oskarżony się poruszał i który swoim zachowaniem uszkodził.

Tok rozumowania przyjęty przez Sąd Rejonowy w Tomaszowie Lubelskim nie jest niestety częstą praktyką w sądownictwie. Prokuratorzy rzadko decydują się na postawienie sprawcy nielegalnych poszukiwań zabytków zarzutu niszczenia zabytku, a sędziowie sporadycznie wymierzają w takich okolicznościach kary $z$ artykułu 108 u.o.z. W powszechnej świadomości ciągle jeszcze panuje przekonanie, że zabytek to obiekt o dokładnie widocznej, własnej formie przestrzennej, a jego ewentualnie zniszczenie czy uszkodzenie musi być wyraźnie dostrzegalne. Wyrok w przedmiotowej sprawie pokazuje, że zabytki archeologiczne stanowią pełnoprawną kategorię zabytków, podlegającą pełnej ochronie prawnej na podstawie ustawy o ochronie zabytków i opiece nad zabytkami. Orzeczenie to stanowi przykład dobrej praktyki w prawnej ocenie działalności osób dokonujących zniszczeń na terenie stanowisk archeologicznych i można mieć nadzieję, że wpłynie na wzrost liczby podobnych interpretacji sądowych w przyszłości.

\section{Bibliografia}

Europejska konwencja o ochronie dziedzictwa archeologicznego (poprawiona), sporządzona w La Valetta dnia 16 stycznia 1992 r., Dz. U. z 1996 r. Nr 120, poz. 564.

Gadecki B., Ustawa o ochronie zabytków i opiece nad zabytkami. Art. 108-120. Przepisy karne. Komentarz, C.H. Beck, Warszawa 2014.

Hołyst B., Motywacyjne uwarunkowania czynu przestępnego, „Zeszyty Naukowe Uniwersytetu Łódzkiego, Prawo", Seria I, 1973, z. 99.

Kobyliński Z., Teoretyczne podstawy konserwacji dziedzictwa archeologicznego, Fundacja „Res Publica Multiethnica”, Instytut Archeologii i Etnologii Polskiej Akademii Nauk, Warszawa 2001.

Kulesza J., Glosa do wyroku sądu apelacyjnego z 27 kwietnia 1999 roku, II AKa 12/99, „Palestra” $2000, \mathrm{nr} 4$.

Kulik M., Komentarz do przepisów karnych ustawy o ochronie zabytków i opiece nad zabytkami, teza 5, LEX [dostęp: 15.03.2017].

Kulik M., Szczekala A., Odpowiedzialność karna za przestępstwo zniszczenia lub uszkodzenia zabytku, w: T. Gardocka, J. Sobczak (red.), Prawna ochrona zabytków, Wydawnictwo Adam Marszałek, Szkoła Wyższa Psychologii Społecznej, Toruń 2010.

17 Ustawa z dnia 6 czerwca 1997 r. Kodeks postępowania karnego, tekst jedn. Dz. U. z 2017 r., poz. 1904. 


\section{ORZECZNICTWO}

Agnieszka Olech

Radecki W., Ochrona zabytków w polskim, czeskim i słowackim prawie karnym, „Prokuratura i Prawo" 2012, nr 4.

Szerer M., Komplikacje zagadnienia „niskich pobudek”, „Palestra” 1972, nr 3.

Śliwka M., Znaczenie zwrotów niedookreślonych na tle orzecznictwa polskiego Trybunału Konstytucyjnego, „Studia luridica Lublinensia” 2010, nr 13.

Trzciński M. , Przestępczość przeciwko zabytkom, „Prokuratura i Prawo” 2011, nr 6.

Trzciński M., Wokół definicji zabytku archeologicznego, „Ochrona Zabytków” 2007, nr 4.

Ustawa z dnia 22 czerwca 2017 r. o zmianie ustawy o ochronie zabytków i opiece nad zabytkami oraz niektórych innych ustaw, Dz. U. poz. 1595.

Ustawa z dnia 23 lipca 2003 r. o ochronie zabytków i opiece nad zabytkami, tekst jedn. Dz. U. z 2017 r., poz. 2187 ze zm.

Ustawa z dnia 6 czerwca 1997 r. Kodeks postępowania karnego, tekst jedn. Dz. U. z 2017 r., poz. 1904.

Wyrok Sądu Najwyższego z dnia 16 listopada 1973 r., sygn. akt II KR 158/73, OSNKW 1974, nr 4, poz. 63.

Wyrok Sądu Najwyższego z dnia 7 marca 1968 r., sygn. akt VI KZP 9/67, OSNKW 1968, nr 5, poz. 51.

Wyrok Sądu Rejonowego w Tomaszowie Lubelskim z dnia 2 lutego 2016 roku, sygn. akt II K $662 / 14$, niepubl.

Wyrok Sądu Okręgowego w Zamościu z dnia 9 maja 2016 r., sygn. akt II Ka 263/16, niepubl. 